STUDIA PRAWNO-EKONOMICZNE, T. CXVIII, 2021

PL ISSN 0081-6841; e-ISSN 2450-8179 $\quad$ s. 139-158

https://doi.org/10.26485/SPE/2021/118/8

\author{
Wioletta BIEŃ* \\ iD https://orcid.org/0000-0003-1882-8423
}

\title{
THE ELECTORAL CYCLE AND THE TAX POLICY OF GMINAS
}

\begin{abstract}
Background: The subject of this study is the implemented tax policy of gminas and its factors. One of the popular concepts explaining changes in tax policy is the theory of the political (electoral) cycle, according to which electoral decisions are highly dependent on the perception of the economic situation. In election years, local authorities usually attempt to lower or avoid raising local taxes. Therefore, the author focuses mainly on recognising the "electoral" motivations of the adopted tax policy based on the example of gminas in the Małopolskie Voivodeship.

Research purpose: The aim of the study is to analyse and evaluate the tax policy of gminas in the context of the impact of the electoral cycle on the level of local taxes and operating surplus, based on the example of gminas in Małopolskie Voivodeship. According to the author, the impact of the political business cycle on the tax policy of Polish gminas can be observed.

Methods: Both quantitative and qualitative methods were applied in the study. The literature on local tax policy and its differentiating factors was reviewed. The methods of descriptive statistics (structure indicators) were used to analyse data from the budget reports of local government units and statements of the National Electoral Commission. An important source of information in terms of qualitative research were the results of the author's own survey conducted among the treasurers of gminas in Małopolskie Voivodeship. They allowed for confrontation of the determined economic patterns with the opinions of entities having the most information about the financial management of local governments at the gmina level.

Conclusions: The analysis of the data confirmed that the role of local taxes in the building of political capital before local elections was practically insignificant. The research did not indicate that there was any connection between the level of local tax rates and the electoral cycle. Tax policy is perceived by the voters as a relatively insignificant aspect of local policy. In election years, lower budget performance of most gminas implies that the political business cycle affects investment expenditures rather than tax revenues.
\end{abstract}

Keywords: political business cycle, electoral cycle, local tax policy, gmina, local taxes.

JEL classification: E62, H20, H71, R58

* Doktor (PhD), Cracow University of Economics, College of Economics, Finance and Law, Institute of Finance, Department of Financial Accounting; e-mail: bienw@uek.krakow.pl 


\section{Introduction}

Local tax policy can be defined as conscious measures taken by the local government in order to achieve the assumed objectives, using appropriately selected methods, which result from the adopted legal and financial standards ${ }^{1}$. According to the theory of public finance and normative standards ${ }^{2}$, local taxes should be the main source of financing local budgets. The significant scope of autonomy in terms of revenue and the powers of individual local governments to lay down their own tax policy rules increase the sense of responsibility for the financial situation of their local communities.

Local communities expect local authorities to have an effective tax policy and, above all, to provide sufficient revenues to finance activities at the local level and to achieve various social and economic objectives.

The fiscal autonomy granted to gminas - within the limits set by law - means that the level of local taxes will to a greater extent depend on the decisions of local authorities. In practice, different types of tax policy may be implemented. According to P. Swianiewicz ${ }^{3}$, four types of gminas' tax policies can be distinguished: liberal (the rates are low for all taxpayers), fiscal (tax rates are high), populist (low rates for residents, due to relations with voters expecting rate cuts, and high rates for businesses); stimulating (low rates for businesses to create better conditions for economic development, and high rates for the group of residents).

It is difficult to clearly indicate the reasons for the visible differentiation in the tax policy of gminas. The diversity of local policies can be explained by referring to social and economic factors. In small gminas, of a rural or semi-rural nature, the relations between the residents (who are both remitters and voters) and representatives of local government are more direct. In such situation the pressure of local communities expecting lower taxation is higher and more effective.

It should be noted that one of the popular concepts explaining changes in tax policy is the theory of the political business cycle (electoral cycle). Accord-

\footnotetext{
P. Felis, Podatki od nieruchomości a polityka podatkowa gmin w Polsce, Oficyna Wydawnicza, Szkoła Główna Handlowa, Warszawa 2015, p. 79.

2 European Charter of Local Self-Government, drawn up in Strasbourg on 15 October 1985, ratified by Poland on 26 April 1993 (Dz.U. 1994, No. 124, item 607), (corrigendum: Dz.U. 2006, No. 154, item 1107), Article 9, http://prawo.sejm.gov.pl/isap.nsf/DocDetails. xsp?id=WDU19941240607; accessed 31.03.2020.
}

3 P. Swianiewicz, Finanse lokalne, teoria i praktyka, Municipium, Warszawa 2004, p. 257. 
ing to this concept, the authorities strive to ensure that the assessment of the economic situation at the time of elections is as good as possible, as it favours the re-election of the governing group. Election decisions are strongly influenced by the perception of the economic situation, which is why in the election years local authorities usually try to increase the level of expenditure and at the same time reduce or avoid raising local taxes ${ }^{4}$. The author attempted to identify the motivations and behaviour of local authorities with regard to local taxes, thus referring to the above-mentioned theoretical concept used in research conducted in other countries ${ }^{5}$. The aim of the study is to analyse and evaluate the tax policy of gminas in the context of the impact of the electoral cycle on the level of local taxes and operating surplus based on the example of gminas in the Małopolskie Voivodeship.

\section{The theory of the political business cycle}

Research to date indicates the existence of politically conditioned economic fluctuations in various parts of the world. S. Verstyuk identified such fluctuations in Ukraine, which were caused by excessive growth of budget expenditure and a growing deficit in pre-election periods ${ }^{6}$. H. Berger and U. Woitek determined cyclical changes in monetary aggregates in election periods in the second half of the 20th century, which demonstrated that the German central bank (Bundesbank) may have abused its independence by supporting the government in pre-election periods ${ }^{7}$. According to S.A. Block, S. Singh and K.E. Ferree, the analysis of empirical data for 1980-1995 with regard to African countries confirmed the existence of a political business cycle ${ }^{8}$.

4 P.E. Mouritzen, Whatis a Fiscal Crisis?, in: P.E. Mouritzen (ed.), Managing Cities in Austerity, Newbury Park, London 1993, p. 19; K. Houlberg, The Fine Art of Creating Local Political Business Cycles: The case of Danish Municipalities 1989-2005, lecture at the XVI Nordic Conference for Local Government Research, Gothenburg 25-27.11.2007.

5 J. Lukomska, P. Swianiewicz, Polityka podatkowa władz lokalnych w Polsce, Municipium SA, Warszawa 2015, pp. 157-166.

6 S. Verstyuk, Electoral Cycles in Ukraine, Economics Education and Research Consortium - Russia and CIS, 2004.

7 H. Berger, U. Woitek, The German Political Business Cycle: Money Demand rather then Monetary Policy, Department of Economics, University of Glasgow, 2000.

8 S.A. Block, K.E. Ferree, S. Singh, Multiparty Competition, Founding Elections and Political Business Cycles in Africa, Oxford University Press, Journal of African Economies 2003/12 (3), pp. 444-468. 
The political business cycle is primarily related to the research by W.D. Nordhaus ${ }^{9}$. In his opinion, the primary objective of political parties is to gain and maintain power. The ruling group strives to make the assessment of the economic situation during the election period as good as possible, which guarantees that the potential successes would be attributed to such group and, consequently, ensures victory in parliamentary elections. Nordhaus assumes that voters have little knowledge of economic processes and "short memory". When making electoral decisions they are guided by the observed unemployment and inflation rates. The Nordhaus model is based on the relationships resulting from the short- and long-term Phillips curve. In order to be successful in elections, the government aims to reduce unemployment immediately before the elections at the cost of disproportionately higher inflation after the elections. Thus, the political business cycle is the government's policy consisting in the periodic stimulation of periods of prosperity and stages of recession.

Undoubtedly, authorities at the central level have a much broader scope of activity than local authorities. It should be noted that this concept was formulated with reference to parliamentary elections. There are also studies presenting similar phenomena in local policies, whereas the local political business cycle does not include the attempts to influence macroeconomic parameters in the short term ${ }^{10}$. L.G. Veiga and F.J. Veiga ${ }^{11}$, when analysing budget expenditure in Portuguese local governments in 1979-2000, proved that decision-makers systematically increased expenditure immediately before the elections. The increase, particularly in investment expenditure, was notable in the election year, and sometimes in the year preceding the elections. This resulted in a lack of effective resource allocation.

P.E. Mouritzen ${ }^{12}$, in his study based on the example of six countries, proved that in election years local authorities increased the level of budgetary expenditure while avoiding raising taxes and local charges. Increased expenditures were mainly financed by short- and long-term loans. The rates of local taxes, particularly those applicable to most voters, would therefore be lower in election years. He suggested that the electoral cycle phenomenon was particularly

9 W.D. Nordhaus, The Political Business Cycle, Review of Economic Studies 1975/42/2, pp. 169-190.

10 J. Lukomska, P. Swianiewicz, Polityka podatkowa..., pp. 23-24.

11 L.G. Veiga, F.J. Veiga, Political business cycle at the municipal level, Public Choice 2007/131/1-2, pp. 45-64.

12 P.E. Mouritzen, The Local Political Business Cycle, Scandinavian Political Studies 1989/12/1, pp. 37-55. 
notable when the bulk of local government budgets originated from local taxes and authorities had more freedom to set their rates. Consequently, this situation led to a reduction of the operating surplus and to an increase in debt. In his analysis of local governments in Denmark, K. Houlberg ${ }^{13}$ proved that the political business cycle was particularly marked by increased current expenditure rather than investment expenditure.

The impact of the electoral cycle on changes in the operating surplus in Polish local budgets was confirmed by the empirical research by P. Swianiewicz. In the context of local tax policies, this impact was particularly notable in the first years after the 1990 local government reform ${ }^{14}$. The phenomenon of the electoral cycle can also be observed in the current tax policy of Polish local governments.

\section{Methodology and scope of the study}

The study is based on the analysis of specialist literature on the subject, both Polish and foreign, as well as on the analysis and interpretation of the results of empirical research on local tax policy and its differentiating factors. The article aims to verify the key research hypothesis, according to which the impact of the political business cycle on the tax policy of gminas can be observed. An important source of information for the development of the empirical part were the reports on the execution of the budget revenue plan of local government units (reports $\mathrm{Rb}-27 \mathrm{~s}$ ) and the reports on the execution of tax revenues of gminas and cities with poviat status (Rb-PDP) in 2006-2018, obtained from the Regional Chamber of Audit in Krakow. This reference was limited to Section 756 - Revenue from corporate entities, from individuals and from other entities without legal personality and expenditure related to its collection, as only this section presented the receipts from all taxes forming part of local budgets. With regard to Section 756, the author focused mainly on Chapter 75616 - Revenue from agricultural tax, forestry tax, inheritance and gift tax, tax on civil law

13 K. Houlberg, The Fine Art of Creating Local Political Business Cycles: The case of Danish Municipalities 1989-2005, lecture at the XVI Nordic Conference for Local Government Research, Gothenburg, 25-27.11.2007.

14 P. Swianiewicz, Finanse samorzadowe: koncepcje, realizacja, polityki lokalne, Municipium, Warszawa 2011, pp. 290-292; P. Swianiewicz, Zróżnicowanie polityk finansowych władz lokalnych, Instytut Badań nad Gospodarką Rynkową, Warszawa-Gdańsk 1996, pp. 10-187; P. Swianiewicz, A. Kurniewicz, Cykl polityczny w opłatach za lokalne ustugi publiczne w Polsce, Studia Regionalne i Lokalne 2018/2, pp. 56-77. 
transactions and local taxes and charges for individuals, under which she analysed two categories of revenue: property tax (Paragraph 031) and agricultural tax (Paragraph 032).

The reported data relate in particular to the realised revenue and expenditure, budget performance and the financial impact of the reduction of the upper rates of selected taxes on individuals in 2006-2018, with a particular focus on election years. In the context of gminas' budget performance, the operating result should be mentioned. The size of the operating surplus (defined as the difference between current revenue and expenditure) may be considered a measure of each gmina's financial standing, informing about the funds remaining after the most important expenditure related to the unit's current operation have been covered. The financial (investment) result is the difference between the gmina's financial revenue and expenditure. In order to determine the actual change of the categories expressed in terms of value, the author analysed changes in the real operating surplus and financial result in constant prices from the base year 2007.

Surveys carried out on the basis of budget reports refer to all gminas (182 units) of Małopolskie Voivodeship, divided into rural (121), semi-rural (47), and urban gminas (11) and 3 cities with poviat status. The analyses took into account the whole budget of a city with poviat status, without separating the gmina part. The data used in the study were also obtained from the official statements of the National Electoral Commission.

The research methods that were applied in the study mainly included descriptive statistical methods (structure indicators) and a survey. The study additionally presents the results of the authors' own analyses based on surveys conducted by the author in April 2019 among the treasurers of gminas in Małopolskie Voivodeship. They allowed for comparison of the determined economic patterns with the opinions and assessments of entities having the most information about the financial management of local governments at the gmina level.

\section{Analysis of the impact of the electoral cycle on local tax policy}

Local tax policy is to a great extent a social policy. This is evidenced by the fact that tax rates are lower in poorer gminas and higher in rich gminas, where a wealthier taxpayer can pay more (Table 1 ).

In Polish gminas, the main objective of local authorities is often not to attract capital and investments, but rather to prevent dissatisfaction of taxpayers who compare tax rates with those of the neighbouring gminas. Such measures are primarily 
motivated to maintain or increase the political capital of local authorities. The conversion of financial capital into political capital is typical in the period immediately before the elections. The motivations for maintaining political capital are the most important in the case of the agricultural tax and the (housing) property tax, which mainly concern residents who are individuals. However, the analysis with the use of data concerning gminas in Małopolskie Voivodeship does not indicate the significance of the election year in the context of tax decisions (Table 1). In the analysed period 2006-2018, identification of the impact of the electoral cycle on the level of local taxes paid by individuals was not possible.

In the case of the agricultural tax, considerable fluctuations can be observed that are related to the specific form of calculating the tax burden depending on fluctuations of the market price of rye. In an attempt to charge relatively stable amounts to the remitters, local governments increased or reduced the rate depending on the fluctuations on the agricultural market, specifically on the rye market The price of rye does not need to be in line with the price developments of other agricultural products and rye itself has long since ceased to be the most common crop in Polish agriculture.

As far as the most efficient local tax (property tax) is concerned, the policy of local governments was stable. The ratio of the lost revenue, due to the reduction of the upper rates of the property tax for individuals, to the total property tax receipts varied in a rather narrow range of $1.5-4 \%$ - in cities with poviat status and $6-8 \%$ in urban gminas. In the analysed period, a tendency to reduce the property tax for individuals was observed in rural gminas and in semi-rural gminas. Rural gminas had the most liberal tax policy towards their residents.

To sum up the analysis, it can be concluded that in the election years 2006, 2010 and 2014 the trend to cut tax rates continued in subsequent post-election years. The results for 2014 were even more surprising in the context of the electoral cycle theory, as the liberalism of tax policy in certain surveyed gminas decreased in the election year. A clear tendency to reduce property tax rates was observed in all types of gminas before the 2017-2018 local elections.

It should be noted, however, that only a small part of local taxes was paid by average residents, with most of the revenues originating from enterprises operating in the gminas. As a result of the very low burden on average voters, the change of tax rates was not perceived as a decision that could bring about a clear change in the voters' sentiments. The limited role of local taxes in Poland may suggest that the impact of the electoral cycle on the level of taxes paid by individuals was very weak. The analysis of statistical data for 2006-2018 confirmed that the role of local taxes in the building of political capital before 


\begin{tabular}{|c|c|c|c|c|c|c|c|c|c|c|}
\hline 赵 & & 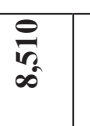 & 0 & $\stackrel{\infty}{\dddot{I}}$ & $\stackrel{\sim}{\sim}^{\infty}$ & 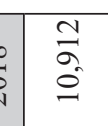 & $\underset{\infty}{\tilde{\infty}}$ & $\tilde{\sigma}$ & 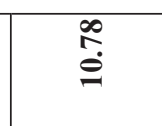 & $\begin{array}{l}\text { to } \\
\text { in } \\
\text { in }\end{array}$ \\
\hline নे & & $\begin{array}{l}\text { d } \\
\text { gे } \\
\text { - }\end{array}$ & 0 & (ָ) & సे & $\stackrel{\infty}{=}$ & হूे & in & $\stackrel{?}{\stackrel{P}{=}}$ & $\begin{array}{l}\overline{\vec{D}} \\
\dot{f} \\
\dot{f}\end{array}$ \\
\hline : & & $\begin{array}{l}\text { वे } \\
\text { तो } \\
\infty\end{array}$ & 0 & $\stackrel{ \pm}{\underset{m}{*}}$ & 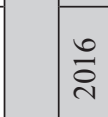 & \begin{tabular}{l}
0 \\
0 \\
\hdashline
\end{tabular} & $\stackrel{n}{\varrho}$ & $\frac{n}{n}$ & $\bar{I}$ & $\begin{array}{l}\hat{\tilde{b}} \\
\text { fं } \\
\end{array}$ \\
\hline 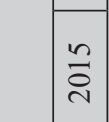 & & $\begin{array}{l}\bar{\infty} \\
\stackrel{0}{\circ}\end{array}$ & 0 & $\stackrel{t}{\stackrel{t}{*}}$ & $\stackrel{n}{a}$ & $\begin{array}{l}\hat{\sigma} \\
\infty \\
\infty \\
\infty\end{array}$ & 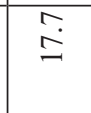 & $\overrightarrow{\vec{b}}$ & $\stackrel{\leftrightarrow}{\Omega}$ & $\begin{array}{l}\tilde{y} \\
\hat{y} \\
\text { ơ }\end{array}$ \\
\hline$\stackrel{\text { aे }}{\overrightarrow{4}}$ & & 免 & 0 & 象 & $\frac{\text { वे }}{ \pm}$ & $\mid \begin{array}{c}\infty \\
\stackrel{\infty}{\infty} \\
\stackrel{5}{=}\end{array}$ & $\stackrel{\tilde{\Theta}}{\tilde{N}}$ & $\overbrace{\infty}^{\infty}$ & $\stackrel{\infty}{\stackrel{\sim}{+}}$ & $\frac{8}{\bar{d}}$ \\
\hline$\stackrel{m}{\vec{i}}$ & & $\begin{array}{l}\text { त्र } \\
\text { I }\end{array}$ & 0 & $\underset{\substack{i \\
i}}{i}$ & $\stackrel{m}{\vec{i}}$ & 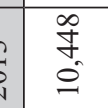 & ב⿱ & $\begin{array}{l}\infty \\
\stackrel{\infty}{\infty} \\
\infty\end{array}$ & 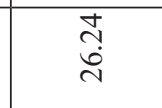 & $\begin{array}{l}\text { mे } \\
\text { qे } \\
\dot{m}\end{array}$ \\
\hline 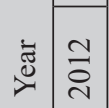 & & 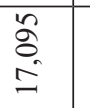 & 0 & $\stackrel{g}{m}$ & $\stackrel{\sim}{\vec{d}}$ & \begin{tabular}{l|l}
$a$ \\
$b$ \\
$b$ \\
$a$ \\
$a$
\end{tabular} & 常 & $\stackrel{R}{i}$ & 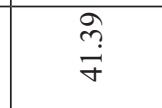 & $\begin{array}{l}\text { ta } \\
\text { d } \\
\text { f }\end{array}$ \\
\hline $\overrightarrow{\vec{\sim}}$ & 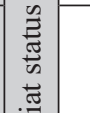 & $\begin{array}{l}\vec{a} \\
\vec{i}\end{array}$ & 0 & $\stackrel{g}{f}$ & 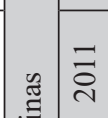 & $\begin{array}{l}\text { in } \\
\text { do } \\
a\end{array}$ & $\begin{array}{l}\infty \\
\stackrel{\infty}{\infty} \\
\stackrel{-1}{n}\end{array}$ & $\stackrel{\hat{N}}{\stackrel{i}{r}}$ & बे & $\begin{array}{l}\text { F } \\
\text { on } \\
\text { f. }\end{array}$ \\
\hline$\stackrel{\circ}{\stackrel{\sim}{े}}$ & 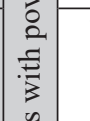 & مُ & 0 & $\hat{\sigma}$ & 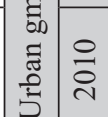 & 莕 & $\stackrel{\overrightarrow{\dot{\theta}}}{\ddot{n}}$ & $\stackrel{\circ}{ }$ & & 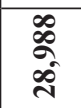 \\
\hline 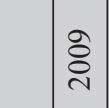 & 湆 & 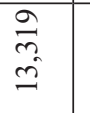 & 0 & लु & ठ্ণे & $\overrightarrow{\widehat{\sigma}}$ & 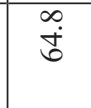 & $\stackrel{R}{8}$ & ) & 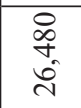 \\
\hline 㐫 & & $\begin{array}{l}\overline{\mathrm{b}} \\
\stackrel{0}{\circ}\end{array}$ & 0 & $\overrightarrow{\vec{i}}$ & : & $\begin{array}{l}\hat{q} \\
\text { s. } \\
0\end{array}$ & ڤ̊ & 胥 & $\begin{array}{l}\stackrel{g}{g} \\
\stackrel{g}{o}\end{array}$ & $\begin{array}{l}\text { के } \\
\text { in } \\
\text { तु }\end{array}$ \\
\hline 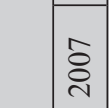 & & $\begin{array}{l}\hat{\Omega} \\
\hat{S}\end{array}$ & 0 & $\stackrel{\text { ă }}{i}$ & : & $\begin{array}{l}\vec{F} \\
\text { g. }\end{array}$ & ? & 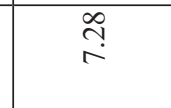 & $\stackrel{n}{n}$ & $\begin{array}{l}\tilde{n} \\
\hat{n} \\
\tilde{d}\end{array}$ \\
\hline ఫ্ণ & & ప్ & $\theta$ & $\underset{\mathrm{i}}{\mathrm{i}}$ & ఫ্ণ & है & 3 & . & İ: & $\begin{array}{l}\text { an } \\
\text { qu }\end{array}$ \\
\hline 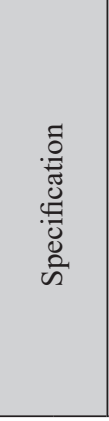 & & 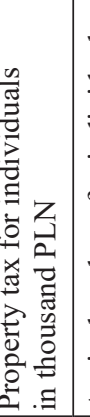 & 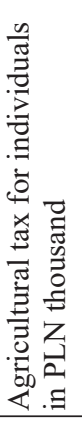 & 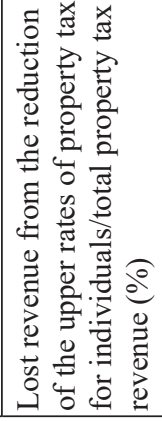 & & 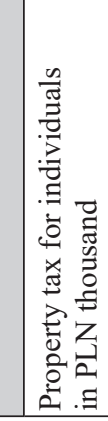 & 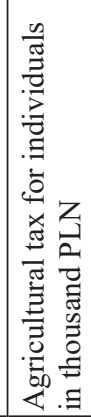 & 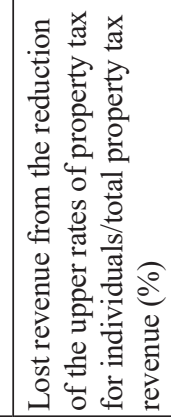 & 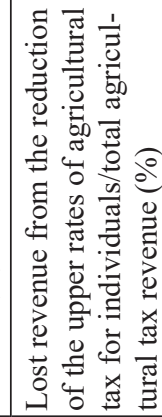 & 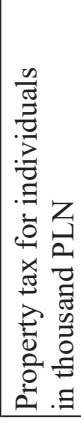 \\
\hline
\end{tabular}




\begin{tabular}{|c|c|c|c|c|c|c|c|c|}
\hline 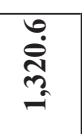 & $\begin{array}{l}\stackrel{N}{0} \\
\stackrel{\theta}{\theta}\end{array}$ & خे & & $\stackrel{\infty}{\stackrel{\infty}{\sigma}}$ & $\frac{\hat{\sigma}}{\hat{\sigma}}$ & 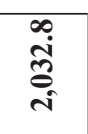 & $\begin{array}{l}\bar{\infty} \\
\stackrel{0}{\sigma}\end{array}$ & $\stackrel{5}{\mp}$ \\
\hline $\begin{array}{l}\stackrel{0}{0} \\
\stackrel{+}{+} \\
\stackrel{-}{-1}\end{array}$ & $\begin{array}{l}\stackrel{2}{a} \\
a\end{array}$ & $\begin{array}{l}\mathscr{b} \\
\dot{\sigma}\end{array}$ & & 공 & 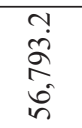 & $\begin{array}{l}\dot{7} \\
\ddot{d} \\
\varnothing \\
i \\
i\end{array}$ & $\frac{\sim}{9}$ & $\stackrel{\infty}{\underset{\forall}{+}}$ \\
\hline $\begin{array}{l}\infty \\
\stackrel{\sim}{\sigma} \\
\sim\end{array}$ & $\begin{array}{l}\hat{\infty} \\
\dot{\sigma}\end{array}$ & $\begin{array}{l}\text { రొ } \\
\text { లె. }\end{array}$ & & $\stackrel{\circ}{\stackrel{\sim}{*}}$ & $\begin{array}{l}\text { Oे } \\
\text { Sิ } \\
\text { î } \\
\text { n. }\end{array}$ & 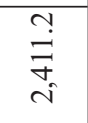 & $\begin{array}{l}\infty \\
\infty \\
\infty \\
-1\end{array}$ & 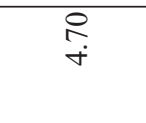 \\
\hline 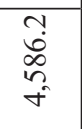 & $\begin{array}{l}\stackrel{0}{\leftrightarrows} \\
=\end{array}$ & $\begin{array}{l}\stackrel{g}{+} \\
\dot{J}\end{array}$ & & $\frac{n}{\tilde{N}}$ & $\begin{array}{l}\text { Na } \\
\tilde{n} \\
\tilde{n} \\
\tilde{n}\end{array}$ & $\begin{array}{l}0 \\
\dot{+} \\
\infty \\
0 \\
0\end{array}$ & $\begin{array}{l}\vec{\exists} \\
\stackrel{\sigma}{\sigma}\end{array}$ & $\begin{array}{l}\tilde{n} \\
\text { in }\end{array}$ \\
\hline 离 & $\stackrel{\circ}{\stackrel{0}{\varrho}}$ & $\underset{⿱}{\stackrel{\gtrless}{*}}$ & & 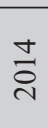 & $\begin{array}{l}\hat{n} \\
\dot{0} \\
\tilde{n} \\
\hat{n}\end{array}$ & $\begin{array}{l}\stackrel{b}{\circ} \\
\stackrel{5}{\hat{\sigma}} \\
=\end{array}$ & $\begin{array}{l}\frac{1}{2} \\
2\end{array}$ & $\begin{array}{l}\stackrel{\ominus}{\Xi} \\
\stackrel{\vec{\lambda}}{ }\end{array}$ \\
\hline 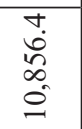 & $\begin{array}{l}\infty \\
\stackrel{\infty}{?} \\
\varrho\end{array}$ & 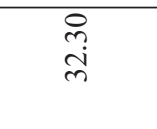 & & $\frac{m}{\stackrel{n}{\sim}}$ & $\begin{array}{l}\tilde{y} \\
\text { ñ } \\
\tilde{n} \\
\text { gे }\end{array}$ & $\begin{array}{l}\stackrel{g}{2} \\
\stackrel{2}{\approx} \\
\stackrel{=}{=}\end{array}$ & 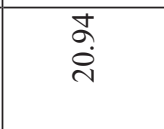 & $\begin{array}{l}\stackrel{n}{m} \\
\frac{\dot{m}}{2}\end{array}$ \\
\hline 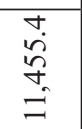 & $\stackrel{\mathfrak{N}}{a}$ & $\begin{array}{l}\hat{0} \\
\text { b }\end{array}$ & & $\stackrel{\sim}{\stackrel{\sim}{*}}$ & 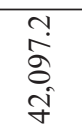 & $\begin{array}{l}\hat{N} \\
\infty \\
\infty \\
\end{array}$ & $\begin{array}{l}8 \\
\stackrel{8}{9}\end{array}$ & 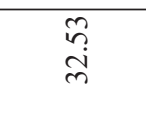 \\
\hline $\begin{array}{l}n \\
\approx \\
\infty\end{array}$ & $\begin{array}{l}\bar{n} \\
\stackrel{0}{0}\end{array}$ & $\hat{m}$ & $\stackrel{\mathscr{E}}{\Xi}$ & $\overline{\stackrel{\nabla}{\sim}}$ & 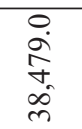 & $\begin{array}{l}\infty \\
\stackrel{0}{0} \\
\stackrel{2}{N}\end{array}$ & $\stackrel{\hat{\imath}}{a}$ & $\begin{array}{l}\hat{\infty} \\
\dot{\sigma}\end{array}$ \\
\hline$\underset{\frac{m}{m}}{\stackrel{+}{0}}$ & ஸे & $\stackrel{\vec{J}}{\ddot{H}}$ & 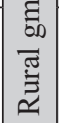 & $\stackrel{\circ}{\stackrel{0}{0}}$ & $\begin{array}{l}\stackrel{0}{\hat{\sigma}} \\
\text { ले }\end{array}$ & $\begin{array}{l}\stackrel{\leftrightarrow}{\circ} \\
\stackrel{\circ}{\circ}\end{array}$ & $\begin{array}{l}\infty \\
\stackrel{\infty}{0} \\
\infty\end{array}$ & $\stackrel{n}{\text { ஸn }}$ \\
\hline $\begin{array}{l}\infty \\
\text { d } \\
0 \\
n \\
n\end{array}$ & $\stackrel{\alpha}{\infty}$ & $\bar{a}$ & & ஓे & \begin{tabular}{l}
$n$ \\
\multirow{2}{n}{} \\
$\infty$ \\
$\infty$ \\
$\infty$ \\
$\sim$ \\
$\sim$
\end{tabular} & $\begin{array}{l}\infty \\
\dot{0} \\
\hat{\sigma} \\
= \\
=\end{array}$ & in & $\begin{array}{l}\hat{a} \\
\stackrel{a}{a}\end{array}$ \\
\hline $\begin{array}{l}\text { Na } \\
\text { on }\end{array}$ & $\underset{\infty}{\stackrel{\infty}{0}}$ & $\begin{array}{l}\infty \\
0 \\
\stackrel{\sim}{\sim} \\
\end{array}$ & & $\stackrel{\infty}{8}$ & $\begin{array}{l}0+ \\
\dot{-} \\
\infty \\
\dot{d}\end{array}$ & $\begin{array}{l}\infty \\
\infty \\
\tilde{\sigma} \\
\infty \\
n\end{array}$ & $\begin{array}{l}\mathscr{2} \\
\dot{0} \\
\dot{1}\end{array}$ & $\begin{array}{l}\infty \\
\mathfrak{\imath} \\
\stackrel{\sim}{2}\end{array}$ \\
\hline $\begin{array}{l}9 \\
\dot{y} \\
\vec{y}\end{array}$ & $\begin{array}{l}n \\
\tilde{n} \\
\sigma\end{array}$ & fु & & $\hat{8}$ & $\begin{array}{l}\overrightarrow{\tilde{N}} \\
\text { d. } \\
\text { ते }\end{array}$ & $\frac{n}{n}$ & $\begin{array}{l}n \\
\stackrel{n}{ \pm} \\
\pm\end{array}$ & $\begin{array}{l}\circ \\
\stackrel{0}{0}\end{array}$ \\
\hline$\underset{m}{\stackrel{v}{m}}$ & స̆. & ભి & & ஓ̊ & $\begin{array}{l}\hat{\tilde{i}} \\
\tilde{\hat{\theta}} \\
\tilde{\mathrm{d}}\end{array}$ & $\dot{q}$ & 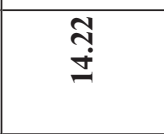 & กึ \\
\hline 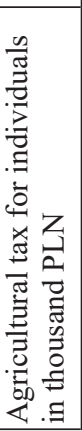 & 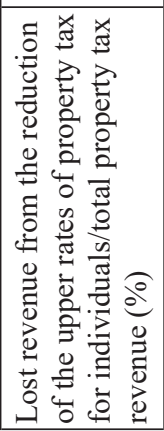 & 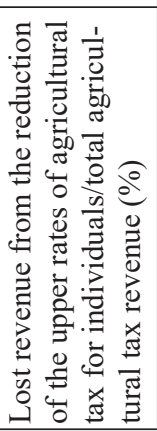 & & & 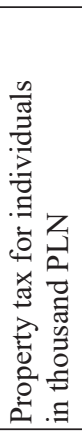 & 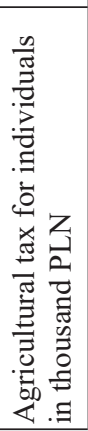 & 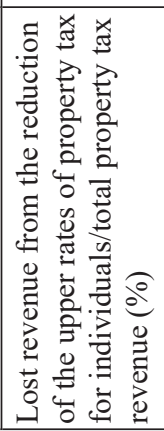 & 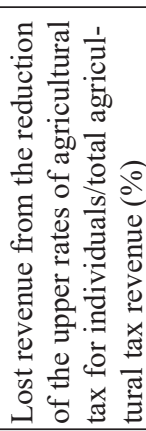 \\
\hline
\end{tabular}


local elections was practically insignificant. Tax policy was therefore not very important in the context of local election campaigns.

A detailed analysis of the problem requires further confirmation whether the patterns resulting from the concept of the electoral cycle are reflected in local spending policy, since they are insignificant on the tax revenue side of gminas. In such situations, the operating surplus ratio may be subject to certain short-term fluctuations resulting from the current policy of local governments. The willingness to gain the voters' support may result in a periodic allocation of part of the surplus to increase current expenditure.

The results from the data of the surveyed gminas' spending policy, presented in Figure 1, did not fully confirm the concept of the electoral cycle. A lower operating surplus in 2010 than in the following years may result from the economic slowdown, difficult financial situation of the remitters and, consequently, deterioration of the revenue situation of the gminas. In this period, the pressure of taxpayers on lowering local taxes may also have been greater. In order to relieve individual taxpayers and provide an impulse for the development of the local economy, gminas decided to reduce the tax burden mainly with regard to individuals.

The above conclusions are confirmed by the figures in Table 1, according to which only the 2010 election year marked the local high for tax liberalism of local governments in all types of gminas. In the next election year (2014), most units reported a significant increase in their operating surplus. The above-mentioned results lead to the conclusion that in the pre-election period gminas limited the growth of current expenditures.

This does not imply that the electoral cycle has no impact on the economic and financial decisions of local governments. The observed relationship between the distance from the elections and the size of gminas' budget performance is an argument that such a relationship exists (Figures 1 and 2). In the election years, the budget performance of most gminas was lower. Therefore, it should be assumed that on the expenditure side, the political business cycle affects investment expenditures rather than current expenditures.

An increase in the level of voter turnout in local elections was also observed. Particularly in rural gminas and in semi-rural gminas, the awareness of the direct impact on the election of local government authorities increased, which is reflected in greater social activation and involvement in social and political life. This is evidenced by the high voter turnout reported in rural (53.6\% in 2018) and semi-rural (51\% in 2014, 50\% in 2018). Gmina residents convinced of their possible impact on local affairs more often participated in the elections (Table 2). 


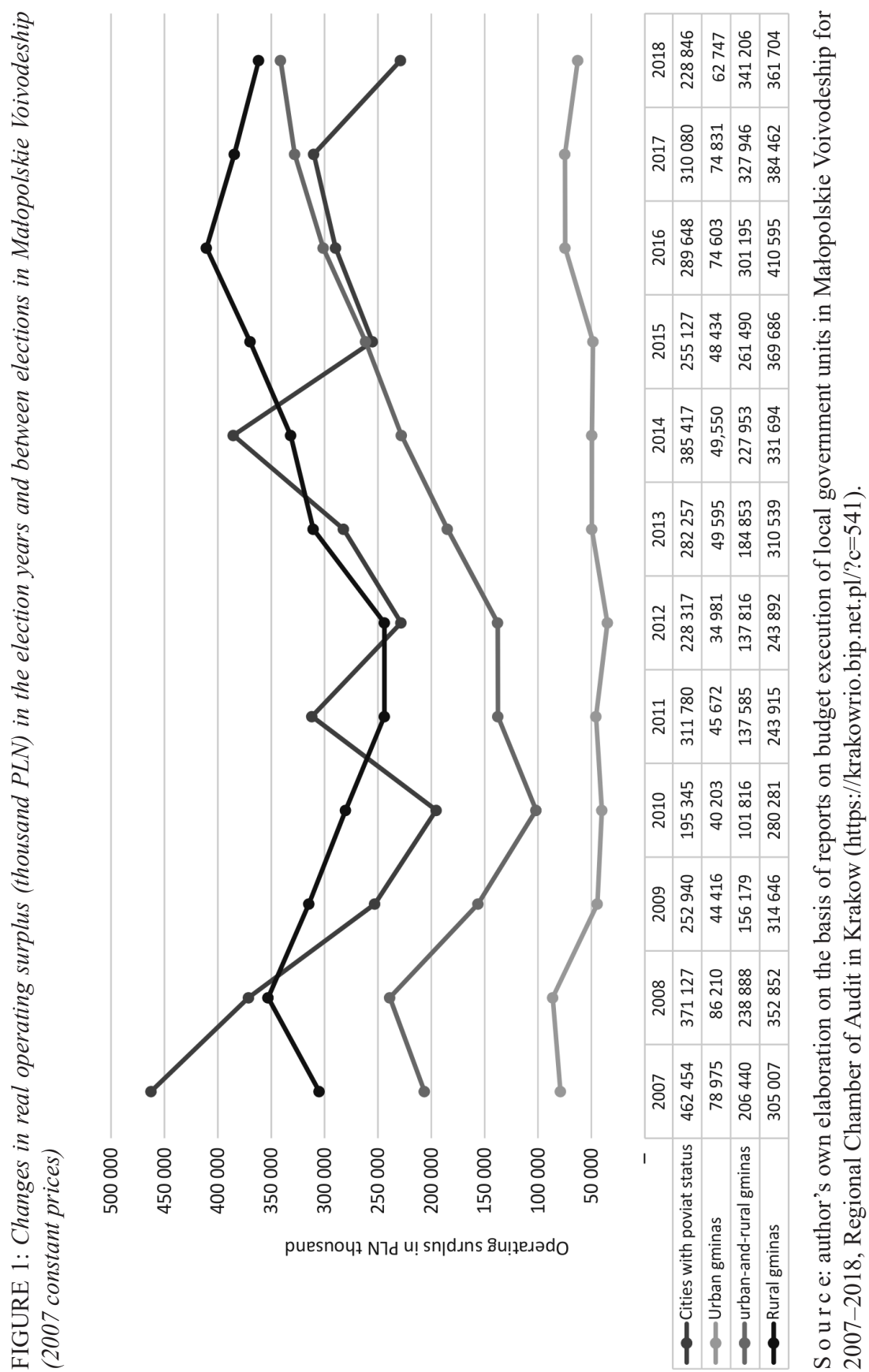




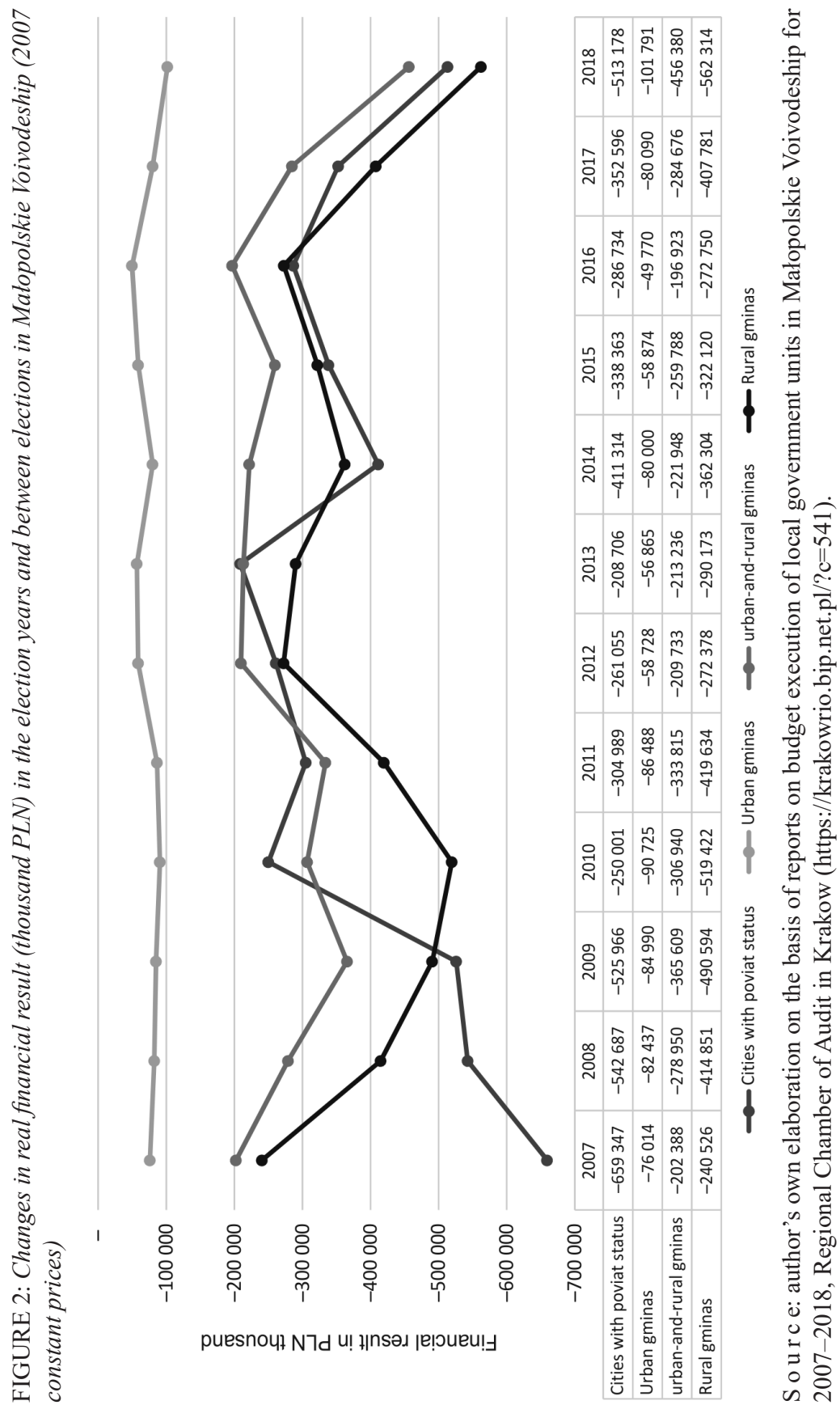


TABLE 2: Voter turnout (\%) in 2006-2018 in respective types of gminas in Matopolskie Voivodeship

\begin{tabular}{|l|c|c|c|c|}
\hline \multirow{2}{*}{ Specification } & \multicolumn{4}{|c|}{ Election years } \\
\cline { 2 - 5 } & 2006 & 2010 & 2014 & 2018 \\
\hline \multicolumn{5}{|c|}{ Cities with poviat status } \\
\hline Average voter turnout & 43.55 & 45.28 & 43.92 & 51.56 \\
\hline \multicolumn{7}{|c|}{ Urban gminas } \\
\hline Average voter turnout & 48.49 & 48.47 & 49.87 & 47.98 \\
\hline urban-and-rural gminas \\
\hline Average voter turnout & 48.08 & 50.90 & 50.86 & 50.00 \\
\hline \multicolumn{7}{|c|}{ Rural gminas } \\
\hline Average voter turnout & 48.98 & 52.43 & 52.98 & 53.60 \\
\hline \multicolumn{7}{|c|}{ Poland } \\
\hline Average voter turnout in Poland & 46.00 & 47.00 & 47.00 & 52.00 \\
\hline
\end{tabular}

S o u r c e: author's own elaboration based on the National Electoral Commission data for 2006, 2010, 2014 and 2018, http://pkw.gov.pl/317_Wybory_samorzadowe_i_referenda_lokalne

Election turnout is an indirect indicator of acceptance or alienation of local government. It can be assumed that in gminas where the turnout was very low members of local authorities had a sense of low legitimacy of power based on social acceptance. On the other hand, the longer the voits and mayors held power, the more important it was for them to meet the expectations of residents-taxpayers regarding the level of local tax rates. As it has been mentioned above, this relationship was most notable in rural gminas.

\section{Survey results}

An important source of information in terms of qualitative research proved to be the results of the author's own survey conducted among the treasurers of gminas in Małopolskie Voivodeship. The survey was aimed at understanding the motivations for the adopted tax policy, including "electoral" motivations. 123 gmina treasurers participated in the survey, with the majority of gminas being rural (65\%), followed by semi-rural $(26.8 \%)$, urban $(5.7 \%)$ and cities with poviat status $(2.4 \%)$. The structure of gminas in the sample reflects the structure of all gminas in Małopolskie Voivodeship.

The most important objective for the authorities of the surveyed gminas was to adjust the tax burden to the wealth of gmina residents. This objective 
was indicated by $26.9 \%$ of the survey respondents, which is a share not significantly different from $25 \%$ at the level of significance of $0.05(\mathrm{p}-\mathrm{value}=0.112)$. The second most important objective of the tax policy was to improve the living conditions of the local community, to develop the infrastructure $(25.6 \%$ of indications), and then to attract external investors, new residents ( $15.5 \%$ of indications) and to increase tax revenues, to improve the gmina's financial situation - fiscal target (13.6\%) and to develop entrepreneurship, specific industries (4.2\% of indications), including crafts and tourism.

According to the respondents, the most important objective of urban gminas and cities with poviat status was to improve the living conditions of the local community, to develop infrastructure, while for rural gminas and semi-rural - to adjust the tax burden to the wealth of the residents (Table 3).

TABLE 3: Responses (\%) to the question about tax policy objectives/goals in 2006-2018 by type of gmina

\begin{tabular}{|l|r|r|r|c|}
\hline \multirow{2}{*}{ Response option } & \multicolumn{3}{c|}{ Type of gmina } \\
\cline { 2 - 5 } & urban & rural & $\begin{array}{c}\text { urban-and- } \\
\text { rural }\end{array}$ & $\begin{array}{c}\text { urban gminas } \\
\text { and cities } \\
\text { with poviat } \\
\text { status }\end{array}$ \\
\hline $\begin{array}{l}\text { Development of entrepreneurship, specific } \\
\text { industries }\end{array}$ & 0.00 & 4.12 & 3.57 & 6.45 \\
\hline Attracting external investors, new residents & 25.00 & 14.95 & 14.29 & 22.58 \\
\hline $\begin{array}{l}\text { Adjustment of the tax burden to the wealth } \\
\text { of the residents }\end{array}$ & 25.00 & 28.87 & 25.00 & 19.35 \\
\hline $\begin{array}{l}\text { Improvement of the living conditions } \\
\text { of local community, infrastructure } \\
\text { development }\end{array}$ & 30.00 & 26.80 & 21.43 & 29.03 \\
\hline $\begin{array}{l}\text { Adjustment of local tax rates to those of } \\
\text { the neighbouring gminas }\end{array}$ & 5.00 & 11.86 & 10.71 & 3.23 \\
\hline $\begin{array}{l}\text { Increase in tax revenues, improvement } \\
\text { of the gmina's financial situation (fiscal } \\
\text { target) }\end{array}$ & 15.00 & 9.79 & 21.43 & 16.13 \\
\hline $\begin{array}{l}\text { Impact on the level of subsidies and grants } \\
\text { from the state budget }\end{array}$ & 0.00 & 3.61 & 3.57 & 0.00 \\
\hline Other purposes & 0.00 & 0.00 & 0.00 & 3.23 \\
\hline Total & 100.00 & 100.00 & 100.00 & 100.00 \\
\hline
\end{tabular}

S o u r c e: own elaboration. 
Apart from the financial factor, the diverse tax policy of gminas is also influenced by social and political factors. Therefore, we focus on the motivations of tax decisions in the context of the impact of the electoral cycle on the tax policy of gminas.

During the analysis of the survey results, one notable aspect was the statements of certain rural gmina treasurers, who accused local authorities of making decisions on the implementation of too liberal tax policy in order to gain voter support. Although the fiscal motivation was most often appreciated by gmina treasurers, who were in charge of financial affairs, there were exceptions. The respondents' statements prove that it was very important for local authorities in certain rural gminas to meet local community expectations. Gmina council members usually showed interest in the implementation of investment projects and the level of investment expenditures, as they were often held accountable by their voters in this respect. Thus, gmina authorities lowered local tax rates for their residents in order to maintain their political capital.

On the basis of the responses, it can be concluded that in $84 \%$ of the surveyed gminas there was a change of local government. The share of such gminas does not differ significantly from $80 \%$ at the significance level of 0.05 (p-value $=0.075$ ). Moreover, as presented in Table 4 , the change of local government in the analysed period occurred in most urban gminas (including cities with poviat status), rural gminas and urban-and-rural gminas.

TABLE 4: Responses (\%) to the question whether in 2006-2018 the local government changed, by type of gmina

\begin{tabular}{|l|c|c|c|c|}
\hline \multirow{2}{*}{ Response option } & \multicolumn{4}{|c|}{ Type of gmina } \\
\cline { 2 - 5 } & urban & rural & urban-and-rural & $\begin{array}{c}\text { urban gminas } \\
\text { and cities with } \\
\text { poviat status }\end{array}$ \\
\hline Yes & 85.71 & 77.50 & 96.97 & 90.00 \\
\hline No & 14.29 & 22.50 & 3.03 & 10.00 \\
\hline Total & 100.00 & 100.00 & 100.00 & 100.00 \\
\hline
\end{tabular}

S o u r c e: own elaboration.

The survey results confirm that in the majority of gminas ( $88 \%$ of the surveyed gminas) the authorities (voit, mayor or president and the composition of the gmina council) were changed by way of local elections (Table 5). The share of such gminas does not differ significantly from $90 \%$ at the significance level 
of 0.05 (p-value $=0.521)$. In the remaining gminas ( $12 \%$ of the surveyed units), the most frequently indicated circumstances of a change of local government power for other reasons (than through local elections) were: death of a council member, resignation of a council member, violation of the statutory prohibition to combine the mandate of a council member with functions specified in separate regulations, or expiration of the mandate during the term (early elections).

TABLE 5: Responses (\%) to the question about the method of changing local government authorities by type of gmina

\begin{tabular}{|l|c|c|c|c|}
\hline \multirow{2}{*}{\multicolumn{1}{|c|}{ Response option }} & \multicolumn{4}{|c|}{ Type of gmina } \\
\cline { 2 - 5 } & urban & rural & $\begin{array}{c}\text { urban-and- } \\
\text { rural }\end{array}$ & $\begin{array}{c}\text { urban gminas } \\
\text { and cities with } \\
\text { poviat status }\end{array}$ \\
\hline By way of local elections & 85.71 & 81.25 & 93.94 & 90.00 \\
\hline For other reasons & 28.57 & 5.00 & 24.24 & 20.00 \\
\hline
\end{tabular}

S o u r c e: own elaboration.

The results of the survey indicate that the change of local authorities by way of local government elections was most often carried out in semi-rural gminas and in urban gminas (including cities with poviat status). The change more often concerned the composition of the decision-making bodies. In rural gminas, local government authorities were replaced to a lesser extent. The greater stability of local government authorities may indicate that the residents of small rural gminas had a better opinion of their authorities than voters from urban gminas.

In cities and in urban-and-rural gminas, the authorities also changed more frequently in the period between local government elections. Three of the surveyed units indicated the need to hold early mayoral elections. There was also a case of dissolving the executive body and subsequent appointment by the Prime Minister of a person who acted as a mayor until a new body was elected. Such measure was applied due to repeated violations of the applicable laws.

It is worth noting that in $98 \%$ of the analysed gminas, successive local governments continued the tax policy of their predecessors. Only in two gminas (Łużna rural gmina and the city of Tarnów) the new local government authorities changed the existing tax policy (Table 6). In the gmina of Łużna, as a result of the change of the Gmina Council after the 2014 elections, its tax policy has changed. From 2015, the Gmina Council has significantly lowered the property tax rates in order to interest potential investors in purchasing land in the gmina. 
TABLE 6: Responses (\%) to the question about the continuation of tax policy in 2006-2018 by successive local government authorities by type of gmina

\begin{tabular}{|l|c|c|c|c|}
\hline \multirow{2}{*}{ Response option } & \multicolumn{4}{|c|}{ Type of gmina } \\
\cline { 2 - 5 } & urban & rural & urban-and-rural & $\begin{array}{c}\text { urban gminas } \\
\text { and cities with } \\
\text { poviat status }\end{array}$ \\
\hline Yes & 100.00 & 98.75 & 100.00 & 90.00 \\
\hline No & 0.00 & 1.25 & 0.00 & 10.00 \\
\hline Total & 100.00 & 100.00 & 100.00 & 100.00 \\
\hline
\end{tabular}

S o u r c e: own elaboration.

Under the tax policy of the city of Tarnów, the new local authorities changed the rules of determining the property tax rates. The changed concerned. the obligation to adopt a new rate of property tax on undeveloped land forming part of the rehabilitation area from $2016^{15}$.

\section{Conclusions}

To sum up the above analyses, it can be concluded that they do not indicate that there is any connection between the level of local tax rates and the electoral cycle. Although it seems that the election motivation does not affect the rates on a massive scale, such situations do occur in individual gminas, as evidenced by the results of the survey. As the distance between the decision-makers (Council members) and the taxpayers is smaller, there may be more resistance among the residents to increase rates in the gmina or to set higher rates than the ones applicable to the neighbouring gminas.

It should be emphasized that local tax policy is influenced, among others, by fiscal inequalities in local governments, the main cause of which is the different level of their economic and social development. Fiscal inequalities in local governments are determined by objective factors, such as: the existing level of economic development, resources of natural goods, specific geographical and functional location, infrastructural and social facilities or the lack thereof. The

15 The amendment of the Act of 12 January 1991 on local taxes and charges (Dz.U. of 2014, item 849 , as amended) with regard to the property tax rate was provided for in the Act of 9 October 2015 on rehabilitation (Dz.U. item 1777), http://prawo.sejm.gov.pl/isap.nsf/DocDetails. xsp?id=WDU20150001777; accessed 31.03.2020. 
economic consequence of large fiscal inequalities in Polish gminas is a diversified local tax policy and a wider fiscal policy. Moreover, the possibilities of gminas' self-governments in the field of tax policy are very limited. When analysing the budgets of gminas, it is possible to notice how marginal financial importance are some taxes and local fees. In the light of the latest research, the level of gminas taxes increases with the wealth of local budgets. The results of the research also showed that factors related to the economic and social environment are much more important in local tax policy than the political processes taking place ${ }^{16}$.

Tax policy is therefore perceived as a relatively insignificant aspect of local policy. Lack of connection between the electoral cycle and local taxes should be explained by the very limited freedom of Polish local governments with regard to tax policy (limited powers of gmina authorities in terms of impact on certain components of fiscal technique), low level of financial independence (limited impact on the amount of own income, a significant part of which is constituted by a general subsidy, earmarked subsidies and shares in income taxes) and the fact that local taxes constitute a low financial burden in the structure of household expenditures ${ }^{17}$. A positive or negative assessment of the local governments' activity and their possible re-election does not depend on the effects of the implemented tax policy, This questioning the electoral cycle explanation.

\section{References}

\section{Acts of law}

Act of 12 January 1991 on local taxes and charges (Dz.U. 2014, item 849, as amended). Act of 9 October 2015 on rehabilitation (Dz.U. 2015, item 1777).

European Charter of Local Self-Government, drawn up in Strasbourg on 15 October 1985, ratified by Poland on 26 April 1993 (Dz.U. 1994, No. 124, item 607), (corrigendum: Dz.U. 2006, No. 154, item 1107).

\section{Studies}

Berger H., Woitek U., The German Political Business Cycle: Money Demand rather then Monetary Policy, Department of Economics, University of Glasgow, 2000.

16 L. Patrzałek, M. Poniatowicz, B. Guziejewska, S. Kańduła, Nierówności fiskalne w samorzadzie terytorialnym. Przyczyny, mechanizmy i instrumenty wyrównywania, Wydawnictwo Uniwersytetu Ekonomicznego we Wrocławiu, Wrocław 2019, pp. 11-33.

17 A. Wyszkowski, L. Zegarowicz, Ocena występowania politycznego cyklu budżetowego w Polsce, Prace Naukowe Uniwersytetu Ekonomicznego we Wrocławiu 2008/509, p. 457;

P. Swianiewicz, A. Kurniewicz, Cykl polityczny..., pp. 60-61. 
Block S.A., Ferree K.E., Singh S., Multiparty Competition, Founding Elections and Political Business Cycles in Africa, Oxford University Press, Journal of African Economies 2003/12 (3), pp. 444-468.

Felis P., Podatki od nieruchomości a polityka podatkowa gmin w Polsce, Oficyna Wydawnicza, Szkoła Główna Handlowa, Warszawa 2015.

Houlberg K., The Fine Art of Creating Local Political Business Cycles: The case of Danish Municipalities 1989-2005, lecture at the XVI Nordic Conference for Local Government Research, Gothenburg 25-27.11.2007.

Lukomska J., Swianiewicz P., Polityka podatkowa władz lokalnych w Polsce, Municipium SA, Warszawa 2015.

Mouritzen, P.E., The Local Political Business Cycle, Scandinavian Political Studies 1989/12/1, pp. 37-55.

Mouritzen P.E., What is a Fiscal Crisis?, in: P.E. Mouritzen (ed.), Managing Cities in Austerity, Newbury Park, London 1993, p. 19.

Nordhaus W.D., The Political Business Cycle, Review of Economic Studies 1975/42/2, pp. 169-190.

Patrzałek L., Poniatowicz M., Guziejewska B., Kańduła S., Nierówności fiskalne w samorządzie terytorialnym. Przyczyny, mechanizmy i instrumenty wyrównywania, Wydawnictwo Uniwersytetu Ekonomicznego we Wrocławiu, Wrocław 2019.

Swianiewicz P., Finanse lokalne, teoria i praktyka, Municipium, Warszawa 2004.

Swianiewicz, P., Finanse samorzadowe: koncepcje, realizacja, polityki lokalne, Municipium, Warszawa 2011.

Swianiewicz, P., Zróżnicowanie polityk finansowych władz lokalnych, Instytut Badań nad Gospodarką Rynkową, Warszawa-Gdańsk 1996.

Swianiewicz P., Kurniewicz A., Cykl polityczny w optatach za lokalne ustugi publiczne w Polsce, Studia Regionalne i Lokalne 2018/2, pp. 56-77.

Veiga L.G., Veiga F.J., Political business cycle at the municipal level, Public Choice 2007/131/1-2, pp. 45-64.

Verstyuk S., Electoral Cycles in Ukraine, Economics Education and Research Consortium - Russia and CIS, 2004.

Wyszkowski A., Zegarowicz Ł., Ocena występowania politycznego cyklu budżetowego w Polsce, Prace Naukowe Uniwersytetu Ekonomicznego we Wrocławiu 2008/509, p. 457.

\section{Websites}

http://pkw.gov.pl/317_Wybory_samorzadowe_i_referenda_lokalne; accessed 31.03.2020.

http://prawo.sejm.gov.pl/isap.nsf/DocDetails.xsp?id=WDU19941240607; accessed 31.03.2020

http://prawo.sejm.gov.pl/isap.nsf/DocDetails.xsp?id=WDU20150001777; accessed 31.03.2020

https://krakowrio.bip.net.pl/?c=541; accessed 31.03.2020. 
Wioletta BIEŃ

\title{
CYKL POLITYCZNY A POLITYKA PODATKOWA GMIN
}

\begin{abstract}
Abstrakt
Przedmiot badań: Przedmiotem badań jest realizowana polityka podatkowa gmin i czynniki ją kształtujące. Jedną z popularnych koncepcji wyjaśniających zmiany w polityce podatkowej jest teoria cyklu politycznego (wyborczego), według której decyzje wyborcze są silnie uzależnione od percepcji sytuacji gospodarczej. Zwykle w latach wyborczych władze samorządowe próbują zmniejszać lub unikać podnoszenia podatków lokalnych. Stąd też uwaga autorki koncentruje się głównie na rozpoznaniu motywów „wyborczych” przyjętej polityki podatkowej na przykładzie gmin województwa małopolskiego.

Cel badawczy: Celem artykułu jest analiza i ocena polityki podatkowej gmin w kontekście wpływu cyklu wyborczego na poziom podatków lokalnych oraz nadwyżki operacyjnej na przykładzie gmin województwa małopolskiego. Autorka stawia tezę, według której można dostrzec zjawisko wpływu cyklu politycznego na politykę podatkową polskich samorządów gminnych.

Metoda badawcza: W artykule zastosowano metody o charakterze ilościowo-jakościowym. Dokonano przeglądu literatury w zakresie lokalnej polityki podatkowej i czynników ją różnicujących. Zastosowano metody statystyki opisowej (wskaźniki struktury), służące analizie danych pochodzących ze sprawozdań budżetowych JST oraz z zestawień Państwowej Komisji Wyborczej. Istotne źródło informacji w zakresie badań jakościowych stanowiły wyniki badania ankietowego przeprowadzonego przez autorkę wśród skarbników gmin województwa małopolskiego. Umożliwiły one konfrontację formułowanych prawidłowości ekonomicznych z opiniami podmiotów najlepiej zorientowanych w problematyce gospodarki finansowej samorządu gminnego.

Wyniki: Analiza danych potwierdziła, iż rola podatków lokalnych w budowaniu kapitału politycznego przed wyborami samorządowymi jest praktycznie niezauważalna. Dokonane badania nie wskazują na występowanie związku pomiędzy wysokością stawek podatków lokalnych i cyklem wyborczym. Polityka podatkowa postrzegana jest przez wyborców jako stosunkowo mało istotny fragment polityki lokalnej. W latach wyborczych niższe wyniki budżetowe większości gmin oznaczają, że cykl polityczny odbija się bardziej na wydatkach inwestycyjnych, a nie dochodach podatkowych.
\end{abstract}

Słowa kluczowe: cykl polityczny, cykl wyborczy, lokalna polityka podatkowa, gmina, podatki lokalne. 